\title{
Correlation between the Body Mass Index (BMI) of Pregnant Women and the Development of Hypotension after Spinal Anesthesia for Cesarean Section
}

\author{
Fernando Souza Nani ${ }^{1}$, Marcelo Luis Abramides Torres ${ }^{2}$
}

Summary: Nani FS, Torres MLA - Correlation between the Body Mass Index (BMI) of Pregnant Women and the Development of Hypotension after Spinal Anesthesia for Cesarean Section.

Background and objectives: Very few publications correlate hypotension in obese pregnant women, and especially morbidly obese, after spinal anesthesia for cesarean section. The objective of the present study was to evaluate the incidence of hypotension according to the BMI.

Methods: Forty-nine patients with pregestational BMI below $25 \mathrm{~kg} \cdot \mathrm{m}^{-2}$ were included in the Eutrophia group, and 51 patients with BMI $\geq 25 \mathrm{~kg} \cdot \mathrm{m}^{-2}$ were included in the Overweight group. After spinal anesthesia, blood pressure, volume of crystalloid infused, and dose of vasopressors used until delivery were recorded. A fall in systolic blood pressure below $100 \mathrm{mmHg}$ or $10 \%$ reduction of the initial systolic blood pressure (SBP) was considered as hypotension and it was corrected by the administration of vasopressors.

Results: Episodes of hypotension were fewer in the Eutrophia group ( $5.89 \pm 0.53$ vs. $7.80 \pm 0.66, p=0.027$ ), as well as the amount of crystalloid administered $(1,298 \pm 413.6 \mathrm{~mL}$ vs. $1,539 \pm 460.0 \mathrm{~mL} ; \mathrm{p}=0.007)$, and use of vasopressors $(5.87 \pm 3.45$ bolus vs. $7.70 \pm 4.46$ bolus; $p=0.023)$. As for associated diseases, we observed higher incidence of diabetes among obese pregnant women $(29.41 \%$ vs. 9.76\%, RR $1.60,95 \% \mathrm{Cl}$ : 1.15-2.22, $\mathrm{p}=0.036$ ), however, differences in the incidence of pregnancy-induced hypertension (PIH) were not observe between both groups (overweight: $21.57 \%$, normal weight: $12.20 \%$, RR 1.30, 95\% Cl: 0.88-1.94, $\mathrm{p}=0.28$ ).

Conclusions: In the study sample, pregestational BMI $\geq 25 \mathrm{~kg} \cdot \mathrm{m}^{-2}$ was a risk factor for hypotension after spinal anesthesia in patients undergoing cesarean section. The same group of patients required higher doses of vasopressors. Those results indicate that the anesthetic techniques in those patients should be improved to reduce the consequences of post-spinal anesthesia hypotension, both in pregnant women and fetuses.

Keywords: Obesity; Obesity, Morbid; Cesarean Section; Anesthesia, Obstetrical; Anesthesia, Spinal.

[Rev Bras Anestesiol 2011;61(1): 21-30] CElsevier Editora Ltda.

\section{INTRODUCTION}

Spinal, epidural, or combined anesthesias are widely used in obstetrics, both for cesarean section and labor analgesia ${ }^{1-3}$. This is due to the proven lower morbidity and mortality ${ }^{1}$ when compared to general anesthesia that has a higher incidence of complications, such as: difficult intubation, rapid desaturation, greater chance of aspiration, and neonatal depression ${ }^{2,4}$, besides the impossibility of keeping the mother conscious for the delivery.

Despite the advantages of regional anesthesia it is not free of complications and already known limitations, such as difficult puncture in some cases, hypotension, total spinal anesthesia, post-dural puncture headache, and nerve lesions ${ }^{2}$. Hypotension is one of the most common complications with an inci-

Received from Hospital das Clínicas da Faculdade de Medicina da Universidade de São Paulo - HCFMUSP, Brazil.

1. Assistant Physician of the Anesthesia Department of Instituto Central do HCFMUSP. 2. Professor, Medical Doctor of Anesthesiology at FMUSP. Supervising Physician of the Anesthesia Department of the Instituto da Criança do HCFMUSP.

Submitted on March 31, 2010

Approved on August 2, 2010.

Correspondence to:

Dr. Fernando Souza Nani

Rua Alves Guimarães, 408, Apto 122

Pinheiros

05410-000 - São Paulo, SP, Brazil

E-mail: fsouzanani@yahoo.com.br dence of $15 \%$ to $33 \%{ }^{5-7}$ in the general population after spinal anesthesia and directly related to greater mortality ${ }^{4}$. In obstetric patients, hypotension is even more worrisome because besides showing greater incidence $(20-100 \%)$ it can have serious maternal-fetal consequences, from an increased incidence of nausea and vomiting to fetal hypoxia due to changes in uteroplacental blood flow with consequent fetal acidosis ${ }^{2,8}$.

Post-regional anesthesia hypotension has several definitions, such as a fall of systolic blood pressure below $100 \mathrm{mmHg}$ or a $10 \%$ to $30 \%$ fall from baseline levels ${ }^{2,9,10}$. Currently, the tendency is to maintain blood pressure as close as possible to the initial levels. Some measures are adopted to prevent hypotension and its consequences, such as moving the uterus to the left, crystalloid or colloid infusion, use of vasopressors like ephedrine and metaraminol, and compression of the lower limbs 2,8-10.

There is a lack of studies comparing complications of spinal anesthesia in pregnant women with increased weight to those of eutrophic patients for cesarean section ${ }^{11}$, including hypotension, which makes this analysis important due to the high incidence of obesity in pregnant women. The objective of this study was to analyze the frequency and severity of hypotension in overweight pregnant women when compared to non-obese pregnant women after regional anesthesia in order to effectively improve anesthesia in this type of patient, analyze the influence of comorbidities, and to determine the hemodynamic behavior pattern within different strata of obese patients $(\mathrm{BMI} \geq 25, \mathrm{BMI} \geq 30$, and $\mathrm{BMI} \geq 35$ ). 


\section{METHODS}

After orientation on the anesthesia procedures and the signing of an informed consent, patients were divided into 2 groups based on pregestational BMI, according to the WHO classification which indicates as eutrophic patients with BMI $\geq 20$, overweight $\geq 25$, obesity $\geq 30$, and morbid obesity $\geq$ 35 . In the Euthropia group, patients with pregestational BMI $<25 \mathrm{~kg} \cdot \mathrm{m}^{-2}$ were included, while in the Overweight group patients with pregestational $\mathrm{BMI} \geq 25 \mathrm{~kg}^{-\mathrm{m}^{-2}}$ were included. Patients on doses of anticoagulants that contraindicated spinal anesthesia, thrombocytopenia, coagulogram changes, maternal cardiopathies, history of coagulopathies, twin pregnancy, and those who refused to participate in the study were excluded. Patients were monitored with cardioscope, non-invasive blood pressure (NIBP), and pulse oximeter. Blood pressure was measured three times at 5-minute intervals, before the spinal block, obtaining the mean systolic blood pressure (SBP) to be used as a baseline for correction of hypotension. Ringer's lactate was infused at the same time anesthesia was administered for a total of $10 \mathrm{~mL} \cdot \mathrm{kg}^{-1}$ until delivery.

After spinal anesthesia with $15 \mathrm{mg}$ of $0.5 \%$ hyperbaric bupivacaine associated with $80 \mathrm{mcg}$ of morphine administered in 70 seconds, the uterus was dislocated, the blood pressure was measured every 2 minutes, volume of crystalloids infused and total doses of vasopressors were recorded. Hypotension was defined as a fall in SBP of $10 \%$ of the baseline or below $100 \mathrm{mmHg}$. In the presence of hypotension the anesthesiologist administered a bolus of $200 \mathrm{mcg}$ of metaraminol or $5 \mathrm{mg}$ of ephedrine, whichever he considered appropriate. All anesthesia techniques, doses, and conduction followed the

Episodes of hypotension ( $n$ )

Figure 1 - Episodes of Hypotension.

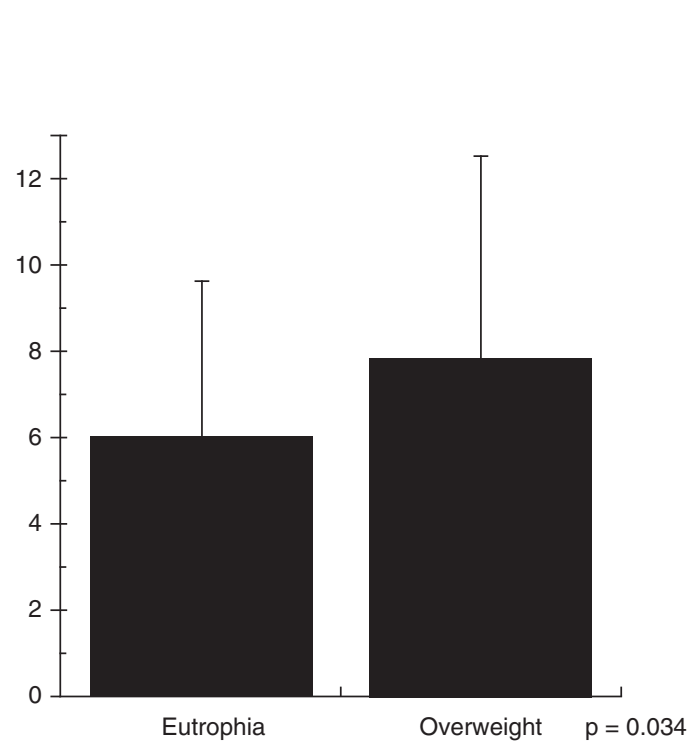

22 standards of Hospital das Clínicas, Faculdade de Medicina of Universidade de São Paulo for cesarean section without changing the anesthetic technique or patient care. Associated diseases were also recorded.

The Student's $t$ test (with Welch correction when indicated) was used to compare means, while the Fisher's exact test was used to compare incidences between the study groups. When analyzing the subgroups of the Overweight group, oneway Analysis of Variance with post-test of Newman-Keuls (or Kruskal-Wallis test with Dunn post-test, whenever indicated) was used. Data were expressed as mean \pm SD (standard deviation) and $p$ smaller than 0.05 was considered significant. The software Prism 5 (GraphPad Software Inc., La Jolla, CA, USA) was used for statistical analysis.

\section{RESULTS}

The incidence of hypotension independently of the number of episodes or their severity was $95.92 \%$ in the Eutrophia group, and $94 \%$ in the Overweight group (NS). After gathering the data and statistical analysis, it was observed that the number of hypotensive episodes were smaller in the Eutrophia group $(5.96 \pm 3.64$ vs. $7.78 \pm 4.73 ; p=0.034)$, which is shown in Figure 1. The volume of crystalloids was also smaller in the Eutrophia group $(1,299 \pm 414 \mathrm{~mL}$ vs. $1,549 \pm 454 \mathrm{~mL} ; \mathrm{p}=0.005)$ shown in Figure 2, and the use of vasopressors was smaller in the Eutrophia group $(5.88 \pm 3.46$ bolus vs. $7.90 \pm 4.78$; $\mathrm{p}=0.017$ ), shown in Figure 3 . The reduction in SBP in relation to initial levels in the Eutrophia group was $24.80 \pm 9.32 \%$ versus $29.28 \pm 13.51 \%$ in the Overweight group ( $p=0.056$ ) shown in Figure 4.
Volume of administered crystalloid $(\mathrm{mL})$

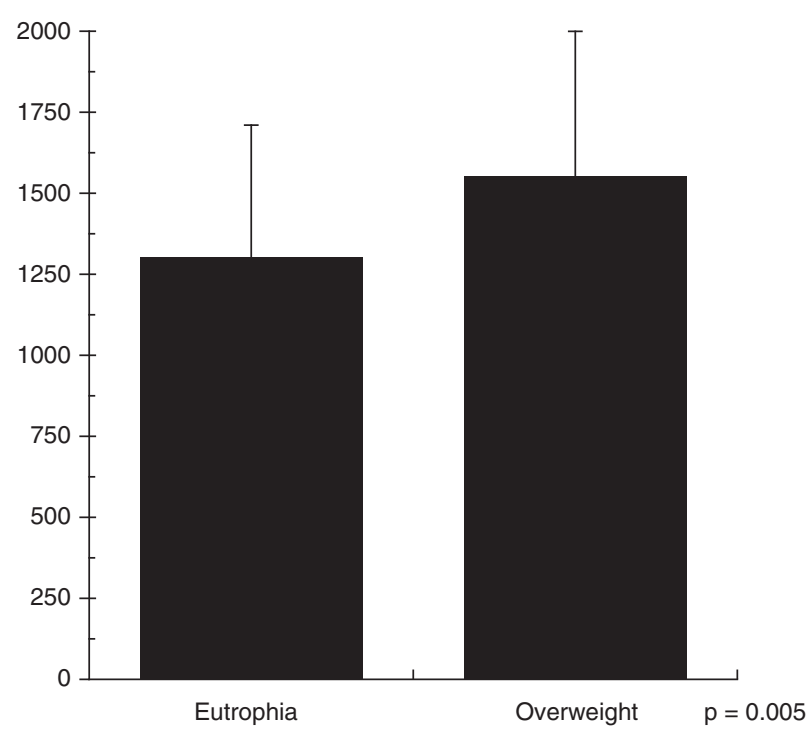

Figure 2 - Volume of Crystalloids. 
Table I - Episodes of Hypotension or Reduction in SBP in Relation to Baseline among the Subgroups

\begin{tabular}{lllll}
\hline Variable & BMI $^{1} 25-30$ & BMI 30-35 & BMI > 35 & p value \\
\hline Reduction in SBP $(\%)$ & $30.57 \pm 11.49$ & $27.69 \pm 10.58$ & $29.20 \pm 16.74$ \\
Episodes of hypotension $(\mathrm{n})$ & $8.53 \pm 4.71$ & $7.31 \pm 3.97$ & $7.48 \pm 5.31$ & 0.851 \\
\hline
\end{tabular}

${ }_{1}^{1}$ Body Mass Index ; ${ }^{2}$ Systolic Blood Pressure.

Regarding associated diseases the incidence of gestational diabetes and pregnancy-induced hypertension $(\mathrm{PIH})$ was analyzed, since those disorders can cause preponderant systemic changes for higher or lower incidence of cases of hypotension. It was observed a higher incidence of diabetes in the Overweight group (29.41\% vs. $8.16 \%$, RR $3.60,95 \% \mathrm{Cl}: 1.28$ $10.1, p=0.009$ ); however, differences were not observed between both groups regarding the incidence of $\mathrm{PIH}$ (overweight:

Bolus of Vasopressors ( $\mathrm{n}$ )

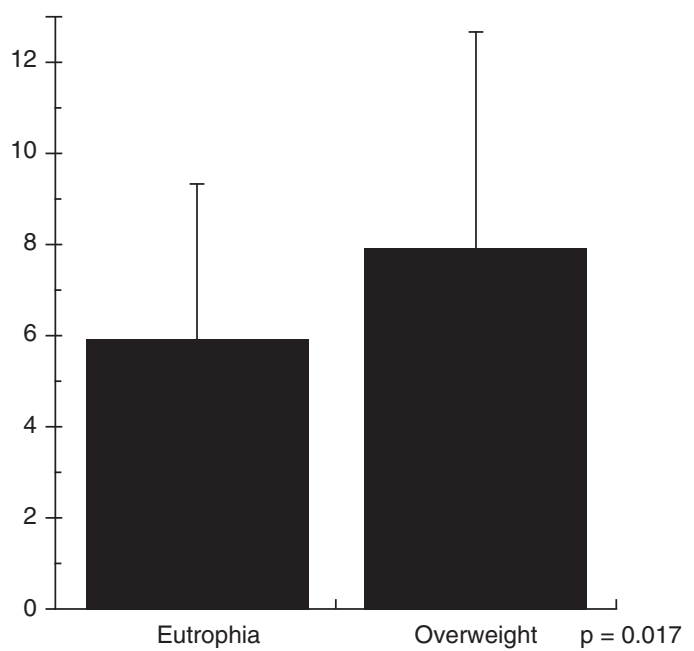

Figure 3 - Bolus of Vasopressors.

Fall in Systolic Blood Pressure (\%)

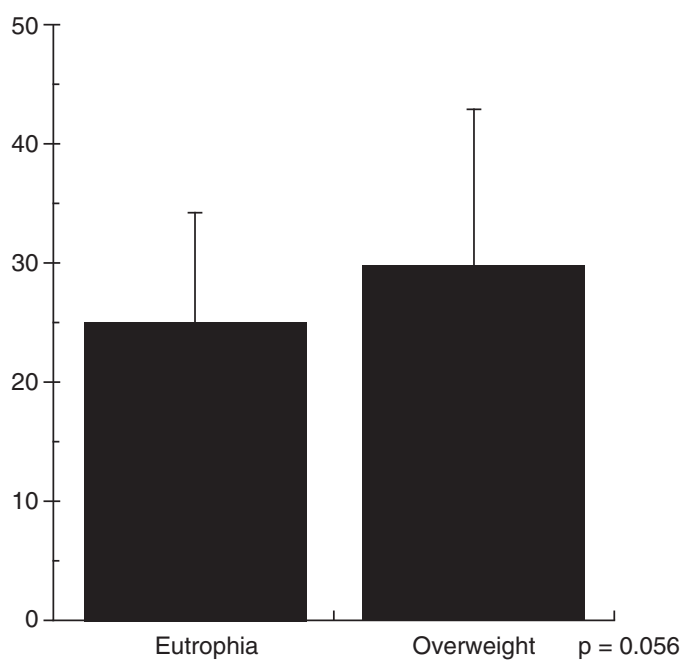

Figure 4 - Fall in Systolic Blood Pressure.
21.57\%, normal weight: $10.20 \%$, RR $2.11,95 \% \mathrm{Cl}: 0.79-5.64$, $p=0.17$ ). One patient was excluded from the Eutrophia group since correction of hypotension did not follow the protocol.

An analysis in 3 subgroups in the Overweight group (BMI $\geq 25$, $\mathrm{BMI} \geq 30$, and $\mathrm{BMI} \geq 35$ ) was also performed; significant differences were not observed in episodes of hypotension or reduction in SBP among the subgroups (Table I).

\section{DISCUSSION}

A significant increase in the incidence of overweight has been observed in the general population characterizing, according to the WHO, a pandemic ${ }^{1,12}$. This increase has also been seen in obstetric patients reaching a prevalence of about $5.5 \%$ during pregnancy according to a Brazilian study ${ }^{13}$ which makes the analysis of this group important for an adequate anesthetic technique. Hartmann et al. ${ }^{6}$ evaluated risk factors for post-spinal anesthesia hypotension in the general population indicating greater risk for patients with a history of hypertension, chronic alcohol abuse, and increased body mass index (BMI), but it excluded obstetric anesthesia.

Pregnancy is associated with some modifications that place the cardiovascular system of pregnant women under stress and when associated with obesity it increases even more the cardiovascular stress. The significant increase in cardiac output, especially during and immediately after labor, reaches up to $75 \%$ above pre-pregnancy levels ${ }^{14,15}$. It exacerbates even more in the obese patient in whom for every $100 \mathrm{~g}$ of increase in the adipose tissue the cardiac output increases by $50 \mathrm{~mL} \cdot \mathrm{min}^{-1}{ }^{15,16}$. Besides, reduction in afterload during pregnancy is less significant in the obese patient due to an increase in peripheral vascular resistance ${ }^{15}$. As a consequence of increased volemia in those patients, initially a left ventricular hypertrophy was observed followed by a gradual dilation of the myocardium against this sustained increase in blood pressure generated by the hypervolemic state, occasionally leading to systolic dysfunction ${ }^{15}$. Pregestational hypertension could be exacerbated and associated with an increase in baseline heart rate and cardiac output, which can lead to diastolic dysfunction. The pulmonary flow increases in the same proportion as the increase in cardiac output and in this hyperdynamic state it leads to pulmonary hypertension, which if sustained can lead to right ventricular failure. Supine position, sleep apnea, and hypoxemia can exacerbate this clinical picture ${ }^{15}$. The possibility of supine hypotension syndrome in those patients increases the morbidity and mortality 15,17 .

Besides those specific changes in the cardiovascular system some hormonal changes are exacerbated by obesity, and they can overload even more cardiovascular functions. 
Hyperinsulinemia and insulin resistance result in fat deposits that might be also seen in the myocardium leading to changes in contractility and conductivity of the cardiac electric stimulus, which makes obese pregnant women more susceptible to arrhythmia, including fatal ones ${ }^{14,15}$. Obesity results in dyslipidemia, endothelial dysfunction, and increased vascular inflammation. This endothelial dysfunction predisposes to the development of pregnancy-induced hypertension ${ }^{15}$. Cardiovascular and Cerebrovascular disease are also worrisome due to the frequent association of obesity and hypertension, type 2 diabetes, hyperlipidemia, and myocardial dysfunction ${ }^{15,18}$. In those patients dilutional anemia compromises transport and tissue delivery of oxygen especially in cases of acute bleeding ${ }^{17}$. The pro-coagulant state associated with decreased mobility makes obese pregnant women a risk group for thrombotic events ${ }^{15,17}$.

Previously obese pregnant women are more prone to antenatal and gestational comorbidities such as chronic hypertension, diabetes, and preeclampsia, besides the greater chance of the development of fetal cardiac anomalies, macrosomia, and fetal shoulder dystocia ${ }^{2}$. Some of those conditions can alter the consequences of anesthesia in those patients. In chronic diabetes, gestational or not, an autonomous neuropathy associated to diabetic cardiomyopathy probably increase the chances of post-regional anesthesia hypotension ${ }^{19}$.

In obese pregnant women undergoing cesarean section, spinal anesthesia remains the most used anesthetic technique 15 due to historical advantages in obstetrics. The association of obesity and pregnancy represents an even higher risk of difficult airways, making it oftentimes a worrisome emergency, since it is associated with slower gastric emptying $15,17,20$. The level of the spinal blockade in those patients when the single dose is used usually becomes more unpredictable and exaggerated than in a normal pregnant woman ${ }^{15}$. This level of unpredictability is probably due to lower volume of cerebrospinal fluid, which is inversely proportional to the increase in BMI, greater compression of the epidural space by the excess weight, engorging of epidural space vessels, and deposit of fat in the epidural space ${ }^{8}$.

Spinal anesthesia is almost always associated with hypotension in a normal pregnancy and it is usually related to aorto-cava compression which can be more important in obese pregnant women. Prophylactic measures for prevention and reduction of maternal hypotension have not been shown to be adequately effective, since they do not prevent the need of intraoperative pharmacologic treatment in those patients, besides being associated to undesirable effects such as the risk of acute pulmonary edema in high risk pregnant women secondary to hypervolemia, hypertension due to the use of vasopressors, fetal acidosis due to the use of ephedrine, and maternal arrhythmias due to the use of phenylephrine ${ }^{8}$. Volemic expansion based on the weight of the patients in the case of morbidly obese pregnant women should be reevaluated due to the risk of hypervolemia, since volume expansion based on total weight can overload maximal cardiac complacency. The use of the corrected weight would be a possibility yet to be determined. It has been proposed that an imbalance between endogenous vasoactive substances especially a reduction in angiotensin II and increase in prostaglandins and nitric oxide are even or more important than the sympathetic blockade and aorto-cava compression in the physiology of hypotension, since patients with preeclampsia are exposed to the same factors and are less subject to episodes of hypotension ${ }^{21}$. Maybe for this reason prophylactic measures against hypotension have little efficacy and the regulation of the vascular tonus especially venous is more important than maintenance of the venous return altered by aorto-cava compression. This might explain the lack of statistical significance in the number of hypotensive episodes and the severity of hypotension among overweight, obese, and morbidly obese patients; i.e., maybe aorto-cava compression is less important than possible metabolic and cardiovascular alterations associated to the increased BMI presented anteriorly.

In view of the data presented here, a more specific management of those patients is necessary. Reduction of local anesthetic doses in spinal anesthesia has been associated with a reduction in the frequency and severity of hypotension, besides the smaller need of pharmacologic treatment ${ }^{8}$. However, a limitation in the time of blockade is observed, for example, between $60-70 \mathrm{~min}$ with doses of 5.5 to $6.5 \mathrm{mg}$ of hyperbaric bupivacaine associated with opioids observed in this study ${ }^{8}$, which for obese patients is a limiting factor due to increased surgical time $8,15,17,22$. This was more exacerbated in teaching hospitals, like ours.

The use of combined anesthetic techniques, such as sequential blockades, represent alternatives for regional anesthesia in this group of patients in several studies, since it has the benefits of smaller doses of intrathecal local anesthetics, besides ending the temporal limitations of the method 8,15,17,22. Despite being promising, the technique does not prevent the difficulties of neuroaxis puncture in obese patients. In cases of ineffective blockade, oftentimes anesthetic complementation via epidural catheter is ineffective for maintaining the quality of adequate anesthesia 8,22 ; therefore, the blockade should be tested and complemented preferentially before the surgical incision to avoid the critical situation of conversion to general anesthesia. We also should take into consideration the need of determining which patients should clearly benefit from the combined technique to adapt it to the clinical, economic, and logistic profile of each patient population.

Maternal obesity has increased significantly; however, the consequence of this new epidemiologic structure has not been investigated. The only study ${ }^{11}$ we could found that effectively presented numerical data on hypotension after anesthesia for cesarean section is a retrospective study that aggregated spinal and epidural anesthesia, did not make it clear the definition of hypotension, and included eutrophic and obese pregnant women in the same group hindering analysis of the data. The specific management of those patients should be viewed as fundamental for maternal-fetal safety, and certainly the development of new prospective studies with combined sequential anesthetic techniques of the neuroaxis are fundamental for the determination of safe and effective doses, in order to establish and conduct anesthesia in those patients. We conclude that overweight patients have higher risk of developing hypotension after spinal anesthesia for cesarean section. 


\section{REFERÊNCIAS / REFERENCES}

1. Saravanakumar K, Rao SG, Cooper GM - Obesity and obstetric anaesthesia. Anaesthesia, 2006;61:36-48.

2. Braveman FR, Scavone BM, Wong CA et al. - Obstetric Anesthesia, em: Barash PG, Cullen BF, Stoelting RK et al. - Clinical Anesthesia. $6^{\text {th }}$ Ed. Philadelphia, Lippincott Williams \& Wilkins, 2009;1137-1170.

3. Cardoso MMSC, Yamaguchi ET, Khouri Filho RA - Analgesia para Trabalho de Parto, em: Cangiani LM, Posso IP, Potério GMB et al. - Tratado de Anestesiologia - SAESP. 6aㅡ Ed, São Paulo, Atheneu, 2006;1783-1790.

4. von Ungern-Sternberg BS, Regli A, Bucher E et al. - Impact of spinal anaesthesia and obesity on maternal respiratory function during elective Caesarean section. Anaesthesia, 2004;59:743749 .

5. Carpenter RL, Caplan RA, Brown DL et al. - Incidence and risk factors for side effects of spinal anesthesia. Anesthesiology, 1992;76:906916.

6. Hartmann B, Junger A, Klasen $\mathrm{J}$ et al. - The incidence and risk factors for hypotension after spinal anesthesia induction: an analysis with automated data collection. Anesth Analg, 2002;94:15211529.

7. Tarkkila $\mathrm{P}$, Isola $\mathrm{J}-\mathrm{A}$ regression model for identifying patients at high risk of hypotension, bradycardia and nausea during spinal anesthesia. Acta Anaesthesiol Scand, 1992;36:554-558.

8. Roofthooft E, Van de Velde M - Low-dose spinal anaesthesia for Caesarean section to prevent spinal-induced hypotension. Curr Opin Anaesthesiol, 2008;21:259-262.

9. Cardoso MMSC, Hirahara JT - Anestesia para Operação Cesariana, em: Cangiani LM, Posso IP, Potério GMB et al. - Tratado de Anestesiologia - SAESP. 6ª Ed, São Paulo, Atheneu, 2006;1791-1804.

10. Morgan Jr GE, Mikhail MS, Murray MJ - Obstetric Anesthesia, em: Morgan GE, Mikhail MS, Murray MJ - Clinical Anesthesiology. $4^{\text {th }} \mathrm{Ed}$, New York, McGraw-Hill, 2006;890-906.

11. Bamgbade OA, Khalaf WM, Ajai $O$ et al. - Obstetric anaesthesia outcome in obese and non-obese parturients undergoing caesarean delivery: an observational study. Int J Obstet Anesth, 2009;18:221225.

12. World Health Organization - Obesity: preventing and managing the global epidemic. Report of a WHO consultation. World Health Organ Tech Rep Ser, 2000;894:i-xii, 1-253.

13. Nucci LB, Schmidt MI, Duncan BB et al. - Nutritional status of pregnant women: prevalence and associated pregnancy outcomes. Rev Saude Publica, 2001;35:502-507.

14. Chang $A B$ - Physiologic Changes of Pregnancy. em: Chestnut DH - Obstetric Anesthesia: Principles and Practice. $3^{\text {rd }}$ Ed. Philadelphia, Elsevier Mosby, 2004;15-36.

15. Roofthooft $E-$ Anesthesia for the morbidly obese parturient. Curr Opin Anaesthesiol, 2009;22:341-346.

16. Veille JC, Hanson R - Obesity, pregnancy, and left ventricular functioning during the third trimester. Am J Obstet Gynecol, 1994;171:980983.

17. Vallejo $\mathrm{MC}$ - Anesthetic management of the morbidly obese parturient. Curr Opin Anaesthesiol, 2007;20:175-180.

18. Tomoda $S$, Tamura $T$, Sudo $Y$ et al. - Effects of obesity on pregnant women: maternal hemodynamic change. Am J Perinatol, 1996;13:7378.

19. Pian-Smith MCM, Datta S, Greene MF - The Diabetic Parturient, em: Datta S - Anesthetic and Obstetric of High-Risk Pregnancy. $3^{\text {rd }}$ Ed, New York, Springer-Verlab, 2004;333-346.

20. Cohn Al, Hart RT, McGraw SR et al. - The Bullard laryngoscope for emergency airway management in a morbidly obese parturient. Anesth Analg, 1995;81:872-873.]

21. Sharwood-Smith G, Drummond GB - Hypotension in obstetric spinal anaesthesia: a lesson from pre-eclampsia. $\mathrm{Br} \mathrm{J}$ Anaesth, 2009;102:291-294.

22. Soens MA, Birnbach DJ, Ranasinghe JS et al. - Obstetric anesthesia for the obese and morbidly obese patient: an ounce of prevention is worth more than a pound of treatment. Acta Anaesthesiol Scand, 2008:52:6-19.

Resumen: Nani FS, Torres MLA - Correlación entre el Índice de Masa Corporal (IMC) de Embarazadas e Hipotensión después de la Raquianestesia para Cesáreas.

Justificativa y objetivos: Existen pocas publicaciones correlacionando la hipotensión en embarazadas obesas y principalmente obesas mórbidas, después de la raquianestesia para cesárea. Deseamos aquí evaluar la incidencia de la hipotensión correlacionada con el IMC.

Método: En el grupo Eutrofia fueron incluidas 49 pacientes con IMC pregestacional por debajo de $25 \mathrm{~kg} \cdot \mathrm{m}-2$ y en el grupo Sobrepeso 51 pacientes con IMC igual o por encima de $25 \mathrm{~kg} . \mathrm{m}-2$. Después de la raquianestesia fueron anotadas las medidas de presión arterial, volumen de cristaloides infundidos y dosis de vasopresores utilizadas hasta el nacimiento. La reducción de la presión arterial sistólica por debajo de $100 \mathrm{mmHg}$ o 10\% de la presión arterial sistólica (PAS) inicial, fue considerado como hipotensión y corregida con vasopresor.

Resultados: Los episodios de hipotensión fueron menores en el grupo Eutrofia $(5,89 \pm 0,53$ vs $7,80 \pm 0,66 ;$ p 0,027); como también la cantidad de cristaloides $(1298 \pm 413,6 \mathrm{~mL}$ vs. $1539 \pm 460,0 \mathrm{~mL} ; \mathrm{p}$ $0,007)$ y el uso de vasopresores $(5,87 \pm 3,45$ bolo vs. $7,70 \pm 4,46$ bolo; p 0,023). En lo concerniente a las enfermedades asociadas, observamos una mayor incidencia de diabetes entre las embara- 
zadas obesas $(29,41 \%$ vs. $9,76 \%$, RR 1,60 , IC $95 \%$ : $1,15-2,22$, p $0,036)$, pero no hubo una diferencia entre los grupos con relación a la incidencia de enfermedad hipertensiva específica de la gestación (DHEG) (sobrepeso: 21,57\%, peso normal: 12,20\%, RR 1,30, IC 95\%: 0,88-1,94, p 0,28).

Conclusiones: En la muestra en estudio, el IMC pregestacional mayor o igual a $25 \mathrm{~kg} \cdot \mathrm{m}-2$ se presentó como un factor de riesgo para la hipotensión después de la raquianestesia en pacientes sometidas a la cesárea. El mismo grupo de pacientes necesitó un número de dosis mayor de vasopresores. La valoración de esos hallazgos nos hace perfeccionar las técnicas anestésicas en esas pacientes para reducir las consecuencias de la hipotensión postraquianestesia, tanto en la embarazada como en el feto.

Descriptores: CIRUGÍA, Obstétrica: cesárea; COMPLICACIONES; Hipotensión arterial; ENFERMIDAD, Obesidad: mórbida; TÉCNICAS ANÉSTESICAS: Regional, raquianestesia. 